\title{
Legacy Effects of Agricultural Practices Override Earthworm Control on C Dynamics in Kiwifruit Orchards
}

\author{
María del Carmen F. Lago', M. Esther Barreal'2, Pedro P. Gallego ${ }^{2}$ and \\ María J. I. Briones ${ }^{1 *}$
}

\begin{abstract}
1 Departamento de Ecología y Biología Animal, Universidade de Vigo, Vigo, Spain, ${ }^{2}$ Departamento de Biología Vegetal y Ciencia del Suelo, Universidade de Vigo, Vigo, Spain
\end{abstract}

OPEN ACCESS

Edited by:

Philippe C. Baveye,

AgroParisTech, France

Reviewed by:

Gerrit Angst,

Institute of Soil Biology (ASCR),

Czechia

Andrey S. Zaitsev,

University of Giessen, Germany

*Correspondence:

María J. I. Briones

mbriones@uvigo.es

Specialty section:

This article was submitted to

Soil Processes,

a section of the journal

Frontiers in Environmental Science

Received: 25 March 2020

Accepted: 21 August 2020

Published: 18 September 2020

Citation:

Lago MCF, Barreal ME,

Gallego PP and Briones MJI (2020)

Legacy Effects of Agricultural Practices Override Earthworm Control on C Dynamics in Kiwifruit Orchards.

Front. Environ. Sci. 8:545609.

doi: 10.3389/fenvs.2020.545609
In Galicia (NW Spain), kiwifruit (Actinidia chinensis var. deliciosa) is intensively produced using conventional practices (CONV) that ensure high yields, despite the fact that the excessive use of agrochemical inputs leads to soil organic matter depletion, increased water pollution and biodiversity losses. Although more sustainable practices have been implemented in the area (i.e., integrated, INT and organic farming, ORG), it remains unclear how these practices will affect $\mathrm{C}$ dynamics mediated by soil biota. Therefore, in this study, we investigated the effects of agricultural management practices and earthworm additions (macrofauna) on soil $\mathrm{C}$ losses $\left[\mathrm{CO}_{2}\right.$ emissions and dissolved organic carbon (DOC)] in relation to the amount of bioavailable soil carbon [salt extractable organic carbon (SEOC) and microbial carbon indicators (microbial biomass or Cmic and the Cmic/Corg ratio)]. The experimental design consisted of a 105days laboratory incubation of intact soil cores collected in the field (40 from each agroecosystem) and earthworm additions over ambient ( $2.43 \pm 0.05$ g/earthworm) to half of the experimental units (+EW), with the remaining half acting as controls. Our results showed that earthworm additions led to significant increases in their abundance in all three management treatments, but with the ORG soils sustaining the greatest population sizes. However, no significant effect on soil $\mathrm{C}$ transformations were observed in response to these earthworm increases, and instead, legacy agricultural practices overrode macrofauna control on C turnover. Consequently, more $\mathrm{C}$ was lost from the CONV treatments than from the ORG ones (on average, 60\% more $\mathrm{CO}_{2}$ and $53 \%$ more DOC) as a result of CONV practices promoting microbial-mediated processes and hence, amplifying $\mathrm{C}$ mineralization versus $\mathrm{C}$ stabilization. Furthermore, $\mathrm{C}$ release from the INT soils was intermediate between the other two treatments, which suggests that more sustainable farming practices could help in achieving climate change mitigation. These findings provide clear evidence of how local adaptation (at farm level) toward a more environmentally friendly land management could represent a promising strategy to increase soil $\mathrm{C}$ sequestration. Future agricultural approaches would need to incorporate the potential benefits from other agroecosystem services beyond those derived from productivity and market values. 


\section{Keywords: Actinidia chinensis, conventional agriculture, integrated production, organic management,} earthworms, microorganisms, soil carbon

\section{INTRODUCTION}

Sustainable agricultural practices, such as integrated (INT) and organic (ORG) farming have been increasingly implemented worldwide to enhance soil organic matter retention (Diacono and Montemurro, 2009), aggregate stability (Bai et al., 2018) and soil biodiversity (Ponge et al., 2013; Henneron et al., 2015) as well as to reduce the negative environmental effects of the more intensive conventional (CONV) agriculture, such as soil erosion (Ordóñez et al., 2007; Verhulst et al., 2010), nutrient losses by leaching or run-off (Riley et al., 2001), greenhouse emissions (Bos et al., 2014), as well as to prevent soil acidification (Otero et al., 2008).

In Spain, the cultivation of the most commercialized cultivar (Hayward) of the green-fleshed kiwifruit (Actinidia chinensis var. deliciosa) is concentrated in the Galician region (NW Spain) by accounting for almost $60 \%$ of the total national production (MAPA, 2019) and thus, representing an important income for rural communities. In this region, kiwifruit is mainly produced using conventional agriculture (CONV) that is characterized by the extensive use of agrochemicals, including pesticides, herbicides, plant growth regulators and mineral fertilizers. Although the number of ORG orchards have increased in the region in recent years, farmers are not fully embracing these sustainable practices due to their lower profitability in terms of crop yields (Seufert et al., 2012). However, controversy remains on the yield gap between ORG and CONV crops (Zuoping et al., 2017; Schrama et al., 2018; Smith et al., 2019), and some of these studies indicate that, after 10-13 years, yields from ORG farming could reach similar values to CONV ones through increased spatial stability of soil abiotic and biotic properties (Schrama et al., 2018). In addition, farming systems not only need to produce more food in a more sustainable way, but also to increase biodiversity and become carbon neutral (European Green Deal: COM/2019/640 final).

A healthy soil hosts an enormous variety of organisms, far exceeding those above ground (Orgiazzi et al., 2016). Among the soil fauna, earthworms (macrofauna) have a positive influence on soil fertility by improving soil physical and chemical properties through the acceleration of organic matter decomposition and nutrient cycling (Bossuyt et al., 2004, 2006; Srinithi and Brian, 2010). These oligochaetes also indirectly induce the production of phytohormones and other plant growth regulators such as enzymes and humic substances (Krishnamoorthy and Vajranabhaiah, 1986; Noguera et al., 2010). However, in cultivated soils, earthworm populations are usually less numerous compared to low disturbed systems, as a result of the negative effects of agricultural practices on their survival (Curry et al., 2002; Postma-Blaauw et al., 2010; Nemecek et al., 2011; Lago et al., 2019). This strong sensitivity to agricultural practices makes this group of invertebrates a reliable indicator of anthropogenic perturbations (Pérès et al., 2008; van Eekeren et al., 2008; PostmaBlaauw et al., 2010). Importantly, intensive agriculture can also alter the structure of their communities, and those species feeding at the soil surface, such as epigeic (which build their galleries in the litter) and anecic earthworms (which live in vertical galleries and ascend to the surface to feed, defecate and mate), are the most severely affected (Briones and Schmidt, 2017; Lago et al., 2019). The loss of these functional groups could have important consequences for soil organic matter transformations, and hence, the balance between $\mathrm{C}$ mineralization and $\mathrm{C}$ stabilization.

Microorganisms also play an important role in $\mathrm{C}$ transformations in agricultural soils (Gougoulias et al., 2014). Microbial biomass carbon (Cmic) is among the most labile pools of organic matter and an important reservoir of plant nutrients (Marumoto et al., 1982) that is also more susceptible to management practices than the bulk organic matter (Janzen, 1987), and hence, a sensitive indicator of changes resulting from agronomic practices (García-Orenes et al., 2013). Consequently, since microbial biomass generally represents $1-4 \%$ of total organic carbon (Corg), both Cmic and the Cmic/Corg, ratio are considered to be useful parameters to monitor soil organic matter changes in response to agricultural conversions than Corg measured alone (Sparling, 1992; Emmerling et al., 2001). From this, most studies indicate that ORG systems have higher microbial biomass than CONV ones (Fließbach and Mäder, 2000; Bünemann et al., 2006; Araújo et al., 2009; Hartmann et al., 2015; Lori et al., 2017), which is largely associated to the application of organic forms of $\mathrm{N}$ instead of mineral fertilizers (Geisseler and Scow, 2014).

Although it is well accepted that agricultural intensification will reduce both macro- and micro-biota, larger animals are more susceptible to be negatively affected (Tsiafouli et al., 2015). Consequently, CONV practices will not only alter the structure of the soil food web (Lago et al., 2019), but also their biotic interactions, which are crucial in regulating $\mathrm{C}$ cycling and storage (Edwards and Fletcher, 1988; Bernard et al., 2012; Medina-Sauza et al., 2019). Microbe-driven turnover is predicted to allow for greater decomposition rates and less soil retention of organic $\mathrm{C}$ (Tardy et al., 2015). However, in the case of earthworms, whether they will increase the amounts of $\mathrm{CO}_{2}$ emitted from these soils (as suggested by a meta-analysis study by Lubbers et al., 2013) or result in less $\mathrm{CO}_{2}$ being released to the atmosphere (Zhang et al., 2013), might depend on other factors, such as the soil physicochemical properties and the earthworm feeding strategies (Singh and Singh, 2019).

Therefore, in this study, we investigated the combined effects of agricultural management practices (here the most commonly used to produce kiwifruits in Galicia: CONV, INT, and ORG) and earthworm additions (two species with different feeding behavior: epigeic and anecic) on soil carbon transformations [i.e., $\mathrm{C}$ assimilated as microbial biomass (Cmic and $\mathrm{Cmic} /$ Corg ratio), stored as easily oxidizable carbon (i.e., salt extractable organic carbon (SEOC)), and released as $\mathrm{CO}_{2}$ and dissolved organic carbon (DOC)] in a mesocosm experiment. We hypothesized that the less intensive managed soils (INT and ORG) will sustain larger earthworm populations than the CONV ones, in particular 
those belonging to the anecic group (Lago et al., 2019) that play a more important role in the translocation of the organic residues down the soil profile and have shown to increase soil $\mathrm{C}$ stocks in their galleries (Don et al., 2008). In contrast, fewer and less diverse earthworm communities in the most intensive agroecosystem will lead to a dominance of microbial-driven processes in the CONV soils leading to faster mineralization processes and greater C losses (Zhang et al., 2013).

\section{MATERIALS AND METHODS}

\section{Kiwifruit Orchards}

The three selected kiwifruit orchards [A. chinensis var. deliciosa (A. Chev.) A. Chev. cv. Hayward] were located in Tomiño (Galicia, NW Spain; $41^{\circ} 58^{\prime} 20^{\prime \prime} \mathrm{N}, 8^{\circ} 46^{\prime} 34^{\prime \prime} \mathrm{W}$ ). The soils in the area can be classified as Dystric or Gleyic cambisols (Merino et al., 2006) and the climate is oceanic, with a mean annual temperature $14.7^{\circ} \mathrm{C}$ and $1283 \mathrm{~mm}$ rainfall fall, on average, every year ${ }^{1}$.

The most intensively managed conventional (CONV) system involves annual applications of high doses of agrochemicals (mineral $\mathrm{N}$ fertilizers and herbicides) and the removal of all thick tree pruning residues from the soil surface in order to prevent fungal infections. The integrated (INT) management also entails annual additions of herbicides and mineral fertilizers, and the removal of all the coarse plant residues, although the thinnest ones are grounded and deposited onto the soil surface. Finally, the organic (ORG) treatment does not apply herbicides but certified organic fertilizers, together with a homemade compost made of pruning residues, poultry slurry and pine needles that provides an input of organic nitrogen to the soil. Land history of the orchards and soil characteristics are shown in Table 1 (for more details about soil physical properties see Lago et al., 2019).

\section{Sampling and Experimental Design}

Intact soil cores were collected in December 2009, coinciding with the dormancy phase of $A$. chinensis life cycle in the northern hemisphere. This was done to ensure low biological activities

${ }^{1}$ www.meteogalicia.gal

TABLE 1 | Agricultural management history, soil texture and chemical inputs at the conventional (CONV), integrated (INT), and organic (ORG) kiwifruit orchards in 2009.

\begin{tabular}{|c|c|c|c|}
\hline & CONV & INT & ORG \\
\hline Cultivated area (ha) & 20.9 & 11.8 & 0.5 \\
\hline Vines plantation (year) & 1987 & 1986 & 1998 \\
\hline Previous use & $\begin{array}{c}\text { Tree } \\
\text { plantation }\end{array}$ & $\begin{array}{c}\text { Tree } \\
\text { plantation }\end{array}$ & $\begin{array}{l}\text { Nursery, greenhouse } \\
\text { crops and fodder } \\
\text { production }\end{array}$ \\
\hline Soil texture & Sandy-loam & Sandy-loam & Sandy-loam \\
\hline $\begin{array}{l}\text { Inorganic N inputs } \\
\left(\mathrm{kg} \mathrm{ha}^{-1}\right)\end{array}$ & 100 & 75 & No applied \\
\hline $\begin{array}{l}\text { Organic N inputs } \\
\left(\mathrm{kg} \mathrm{ha}^{-1}\right)\end{array}$ & No applied & No applied & 170 \\
\hline$P$ inputs $\left(\mathrm{kg} \mathrm{ha}^{-1}\right)$ & 54 & 20 & 43 \\
\hline
\end{tabular}

at the start of the experiment and hence, a minimal influence of plant-soil biota interactions. Forty intact soil cores were randomly taken at each CONV, INT, and ORG orchard using PVC tubes $(11 \mathrm{~cm}$ diameter $\times 20 \mathrm{~cm}$ deep $)$ from three different areas (sectors) to account for local spatial heterogeneity. Each individual core was introduced in a sealed labeled plastic bag for their transport back to the laboratory, and stored in a cold room at $4^{\circ} \mathrm{C}$.

Next, earthworms were added to half of the cores [60 experimental units (+EW), 20 for each management treatment], while the other half acted as controls (60 experimental units, 20 for each management treatment). The two most abundant Lumbricus species present at the investigated area (Lago, 2015) were selected for the +EW treatment. This was to include two different earthworm ecological categories based on their feeding and burrowing behavior (epigeic: Lumbricus rubellus and anecic: Lumbricus friendi), and which are known to be the most sensitive groups to agricultural practices (Briones and Schmidt, 2017). A total number of 236 earthworms were selected for the experiment, and these earthworms (fresh weight $2.43 \pm 0.05 \mathrm{~g}$ /earthworm or $3.93 \pm 0.15$ individuals) were added to each $+\mathrm{EW}$ core. Two nylon meshes $(1 \mathrm{~mm}$ mesh size) were fitted at both ends of each PVC cylinder to prevent earthworms from escaping.

The experimental design was a balanced complete factorial design, with two fixed factors (agricultural management and earthworm addition) and 20 replicates. The 120 experimental units were incubated in an environmentally controlled chamber ("walk-in" type) by randomly assigning two replicates of each treatment to 10 blocks ( 3 agricultural managements $\times 2$ earthworm treatments $\times 2$ replicates $=12$ units per block). The chamber was set at a temperature of $9.0^{\circ} \mathrm{C}$ to mimic the climatic conditions in the field [according to the meteorological data provided from the nearest meteorological station (Areas: $\left.42^{\circ} 1^{\prime} 54^{\prime \prime} \mathrm{N}, 8^{\circ} 40^{\prime} 2^{\prime \prime} \mathrm{W}\right)$, during the winter of 2008-2009 the mean air temperature was $9.1^{\circ} \mathrm{C}$; see "footnote $1^{\prime}$ "]. In addition, the photoperiod cycle was also programmed according to the typical winter conditions measured at the studied area (10:14 h day:night; Rede de Avisos Agrícolas, 2009). Relative humidity and light intensity inside the chamber were also continuously monitored by means of temperature and humidity data-loggers (H08-001-02, $\left.\mathrm{HOBO}^{\circledR}\right)$ and a digital lux meter (LX-101, Lutron), respectively. Throughout the whole incubation period, relative humidity was on average $63.6 \%$ and light intensity $20 \mu \mathrm{mol}$ $\mathrm{m}^{-2} \mathrm{~s}^{-1}(\approx 1050 \mathrm{lux})$. Soil moisture was kept constant (at field capacity) by regular weighing and adding distilled water to compensate for any weight losses. Emerging grasses were also regularly eliminated by hand.

The total duration of the experiment was 105 days (15 weeks) with five destructive samplings every 21 days ( 3 weeks) of four replicates from each treatment ( 3 agricultural managements $\times 2$ earthworm treatments $\times 4$ replicates $=24$ experimental units) randomly selected from the 10 blocks.

\section{Sample Analyses}

Soil respiration from each experimental unit was measured after $21,42,63,84$, and 105 days of incubation using an infrared 
gas analyzer (MGA ADC-3000). On each sampling occasion and under dark conditions, each soil core was placed into an air-tight glass jar $(1250 \mathrm{~mL})$ which was fluxed with $\mathrm{CO}_{2}$-free air for $120 \mathrm{~s}$ followed by immediate measurements of $\mathrm{CO}_{2}$ production ( $\mathrm{t} 0$ ) and after $30 \mathrm{~min}$ incubation ( $\mathrm{t} 30$ ) to enable the calculation of the soil respiration rate from each experimental unit. Respiration data were expressed as $\mu \mathrm{g} \mathrm{CO}_{2}-\mathrm{C} \mathrm{g} \mathrm{dw}$ soil $^{-1}$ day $^{-1}$.

After $\mathrm{CO}_{2}$ measurements, cores were leached with $250 \mathrm{~mL}$ of distilled water that was added to the soil surface, left it drain under gravity and reapplication of the leachate to the surface of the soil twice to ensure a thorough equilibration the mineralized nutrients between the soil and the leachates (Anderson and Ineson, 1982). Collected leachates were filtered (FilterLab $^{\circledR}$, Ref 1252) and a subsample of $50 \mathrm{~mL}$ was used for chemical analyses: (i) DOC using a continuous flow autoanalyzer (Sievers Innovox TOC Analyzer); (ii) total dissolved N (TDN); (iii) dissolved inorganic $\mathrm{N}$ (DIN) by colorimetry using a Bran C Luebbe-AA3 continuous flow autoanalyzer (Bran C Luebbe, Norderstedt, Germany). DON concentrations in the soil solution were calculated as the difference between TDN and DIN. Results were expressed as $\mathrm{mg} \mathrm{kg}^{-1}$ soil dw.

Following these procedures, the 24 experimental units were dismantled and the earthworms hand-sorted and counted (those from the +EW treatments also weighed to obtain their total fresh biomass) and three soil samples from each core were taken for estimation of microbial biomass $\mathrm{C}$ (Cmic), SEOC, and total content of $\mathrm{C}$ and $\mathrm{N}$.

Soil microbial carbon was determined by the fumigationextraction method (Vance et al., 1987), which involves the fumigation of one sample with ethanol-free chloroform followed by extraction of the organic carbon from the fumigated and nonfumigated samples with $100 \mathrm{~mL}$ of $0.5 \mathrm{M} \mathrm{K}_{2} \mathrm{SO}_{4}$. The organic $\mathrm{C}$ content from all samples (non-fumigated and fumigated) was quantified using the continuous flow autoanalyzer (Innovox TOC Analyzer, Sievers), with the results from the non-fumigated sample representing the salt-extractable organic $\mathrm{C}$ (Makarov et al., 2015). Microbial biomass $C$ was calculated according to the following formula:

$$
\mathrm{Cmic}=\frac{\mathrm{Ec}}{\mathrm{Kc}}
$$

where $\mathrm{E}_{\mathrm{C}}$ is the difference between the organic $\mathrm{C}$ extracted from fumigated soils and the organic $\mathrm{C}$ extracted from non-fumigated soils and $\mathrm{Kc}$ is the fraction of mineralized $\mathrm{C}$ (with takes the value of 0.45 in mineral soils; Wu et al., 1990). Final results were expressed in $\mathrm{mg} \mathrm{C}^{-1}$ soil $\mathrm{dw}$.

The third soil sample taken from each dismantled experimental unit was air dried and then sieved $(<2 \mathrm{~mm})$ to measure the total soil carbon (C) and nitrogen (N) contents. This was achieved after combustion using an elemental analyzer (CN-2000, LECO Corp., St Joseph, MI, United States) with the results being expressed as percentage. Finally, the $\mathrm{C} / \mathrm{N}$, microbial carbon to organic carbon (Cmic/Corg) and DOC/DON ratios were also calculated.

\section{Statistical Analyses}

All investigated variables were tested for normality and homoscedasticity using the Kolmogorov-Smirnov and Levene tests, respectively. Accordingly, earthworm numbers and biomass, $\mathrm{CO}_{2}$ emissions, SEOC, and the $\mathrm{C} / \mathrm{N}, \mathrm{Cmic} / \mathrm{Corg}$ and DOC/DON ratios failed to meet these two criteria and they were $\log$ transformed $[\log (\mathrm{x}+1)]$ before performing the parametric analyses. Two-way analysis of variance (ANOVA) was carried out to test the effects of the experimental treatments (earthworm additions and agricultural management practices) on averaged values of all variables investigated. Since earthworm additions did not have a significant effect on the studied variables, repeated measures of ANOVA was then used to test the effects of incubation time and its interaction with treatment (agricultural management combined with earthworm additions as a fixed factor) to test for differences between sampling times and between treatments per sampling time. Separation of means was determined using Tukey's Studentized range (HSD) test $(\alpha=0.05)$. All statistical analyses were performed using SAS (version 9.3) (Sas Institute Inc, 2011).

\section{RESULTS}

\section{Earthworm Populations}

Earthworms added to the +EW experimental units significantly increased the population sizes naturally present in these soils $(p<0.0001)$, resulting in the $+\mathrm{EW}$ treatments having $3.9 \pm 0.25$ individuals on average, when compared to those recorded in the control ones $(0.87 \pm 0.20$ individuals $)$ and this difference was observed in all three management treatments throughout the whole duration of the incubation period (Figure 1). In addition, although more earthworms were found in the ORG treatments (on average) when compared to those in the INT and CONV ones (Figure 1), the differences were not significant ( $p=0.1507$ for the interaction between earthworm additions and agricultural management). Interestingly, the observed temporal changes in the earthworm numbers and biomass in the $+\mathrm{EW}$ treatments showed that the populations of the CONV treatment consisted of fewer but bigger specimens than in the other two treatments where the two curves showed similar changes over time (Figure 2).

\section{Effects of Agricultural Practices and Earthworm Additions on C Transformations}

Agricultural management practices had a significant effect on all variables investigated with the exception of Cmic, SEOC and the DOC/DON ratio (ANOVA, $p<0.05$; Table 2 ). Accordingly, the CONV and INT systems had the highest $\mathrm{C} / \mathrm{N}(\approx 14)$ and Cmic/Corg ratios (20-24\%) compared to the ORG one, but the most intensive management released, on average, significantly more $\mathrm{CO}_{2}$ (37 and 60\% more than the INT and ORG treatments, respectively) and DOC (60 and 53\% more than the INT and ORG treatments, respectively) (Table 2). These findings were a consequence of the significant positive relationship between the 


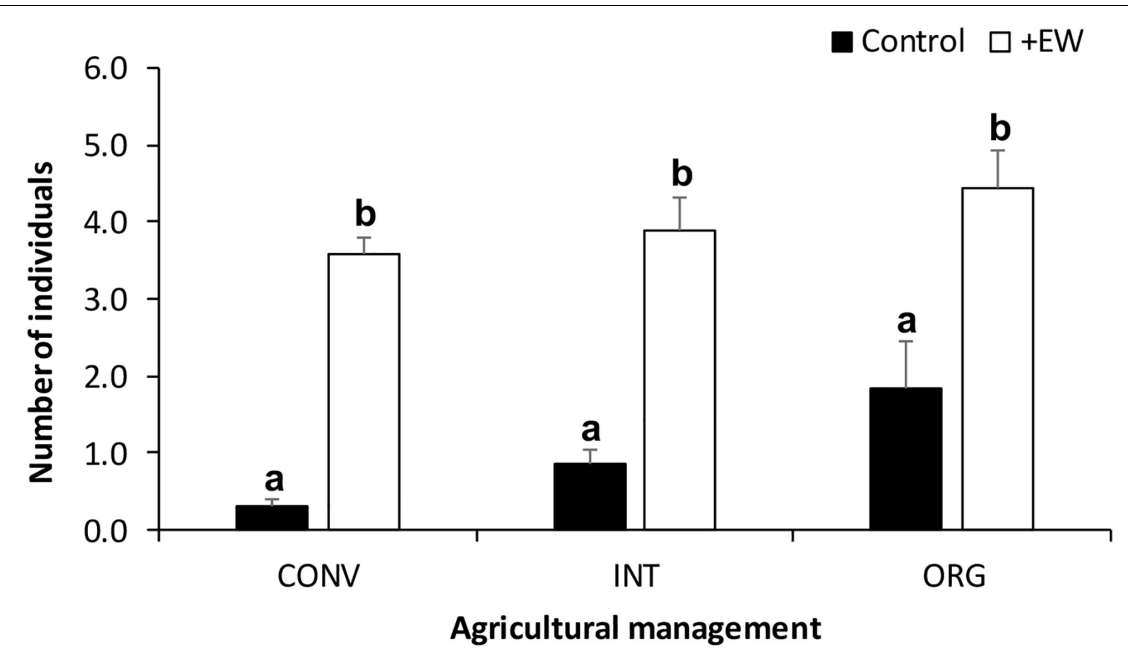

FIGURE 1 | Number of earthworms collected in the soil cores (mean \pm S.E.) from each agroecosystem (CONV, INT, and ORG) and incubated during 105 days. Different letters represent significant differences between earthworm treatments per agricultural management treatment $(p<0.05)$.

ratio of microbial biomass carbon to soil organic carbon and $\mathrm{C}$ release $\left(\mathrm{CO}_{2}: r=0.4319\right.$ and $p<0.0001$ and DOC: $r=0.2747$ and $p=0.0032$ ). However, in contrast to our hypothesis, neither earthworm additions nor their interaction with agricultural management had a significant effect on the overall averaged values of these variables. However, it is noteworthy that, in the control treatments, DOC production was not linked to any microbial indicator whereas soil respiration was accelerated by higher values of these two microbial parameters (Cmic: $r=0.3106$ and $p=0.0187$; Cmic/Corg: $r=0.45458$ and $p=0.0003$ ).

The results from the repeated measures of ANOVA indicated that the incubation time had a significant effect on both oxidizable and microbial carbon but not on the $\mathrm{C} / \mathrm{N}$ ratio (Table 3 and Figure 3A). Accordingly, SEOC showed significant temporal variations, but with all treatments showing similar increases and decreases (Figure 3B). Similarly, the average values of both $\mathrm{Cmic}$ and $\mathrm{Cmic} / \mathrm{Corg}$ ratio did not differ between treatments during the first 84 days of incubation, although with higher values being measured in the two CONV treatments (Figures 3C,D). However, at the end of the experimental period, significant increases in the mean values of these two microbial indicators were observed, but not treatment effects (Figures 3C,D).

Significant temporal changes were also observed for soil respiration rates and the $\mathrm{DOC} / \mathrm{DON}$ ratio but not for $\mathrm{DOC}$ release (Table 3 and Figure 4), and while $\mathrm{CO}_{2}$ emissions increased over time, the DOC/DON ratio decreased over the same time period (Figures 4A,C). Furthermore, the interaction between time and experimental treatment had a significant effect on DOC release and the DOC/DON ratio (Table 3). Accordingly, the soils under CONV management released more DOC during the whole investigated period, more so in response to earthworm additions (Figure 4B). Thus, after 105 days of incubation, the $\mathrm{CONV}+\mathrm{EW}$ treatment released 1.5 times more DOC than the controls (Figure 4B). In contrast, the DOC/DON ratio showed more variability over time and by the end of the experimental period, the two ORG treatments showed the highest values compared to the two INT and CONV ones ( $p<0.05$; Figure 4C).

Cumulative values over the course of the entire experimental period (Figure 4 insets) indicated that, under intensive agricultural management practices, soils lost a total amount of $88.4 \mu \mathrm{g} \mathrm{C} \mathrm{g}^{-1}$ soil $\mathrm{dw} \mathrm{d}^{-1}$ to the atmosphere and $18.8 \mathrm{mg} \mathrm{C} \mathrm{kg}^{-1}$ soil dw into the soil solution, and thus doubled those measured in the ORG soils ( $36.4 \mu \mathrm{g} \mathrm{C} \mathrm{g}^{-1}$ soil $\mathrm{dw} \mathrm{d}^{-1}$ and $9.9 \mathrm{mg} \mathrm{C} \mathrm{kg}^{-1}$ soil dw, respectively). The INT system occupied an intermediate position in relation to $\mathrm{CO}_{2}$ emissions but lost similar amounts of DOC to ORG soils (Figures 4A,B insets).

\section{DISCUSSION}

In agreement with previous studies, more environmentally friendly ORG practices favored earthworm populations, both in terms of numbers and biomass, when compared with those soils that have been subjected to more intensive agricultural practices (e.g., Benge et al., 2007; Carey et al., 2009; Henneron et al., 2015; Briones and Schmidt, 2017; Lago et al., 2019). This is a consequence of the detrimental effects of CONV agriculture on their survival (Curry et al., 2002; van Eekeren et al., 2008; Postma-Blaauw et al., 2010; Nemecek et al., 2011), and more specifically, in this study, the use of mineral fertilizers and herbicides in the INT and CONV treatments. The fact that this management effect remained for the whole duration of the incubation experiment (i.e., more than 3 months) suggests that the legacy effects of agricultural management practices can override the influence of the abiotic (here, constant temperature and moisture levels during the incubation) and biotic factors (here, earthworm additions). Similar legacy effects of previous land uses on soil biota have been previously reported (Crotty et al., 2016; Jernigan et al., 2020), and Briones and Schmidt (2017) found that the positive effects of the conversion to 
A

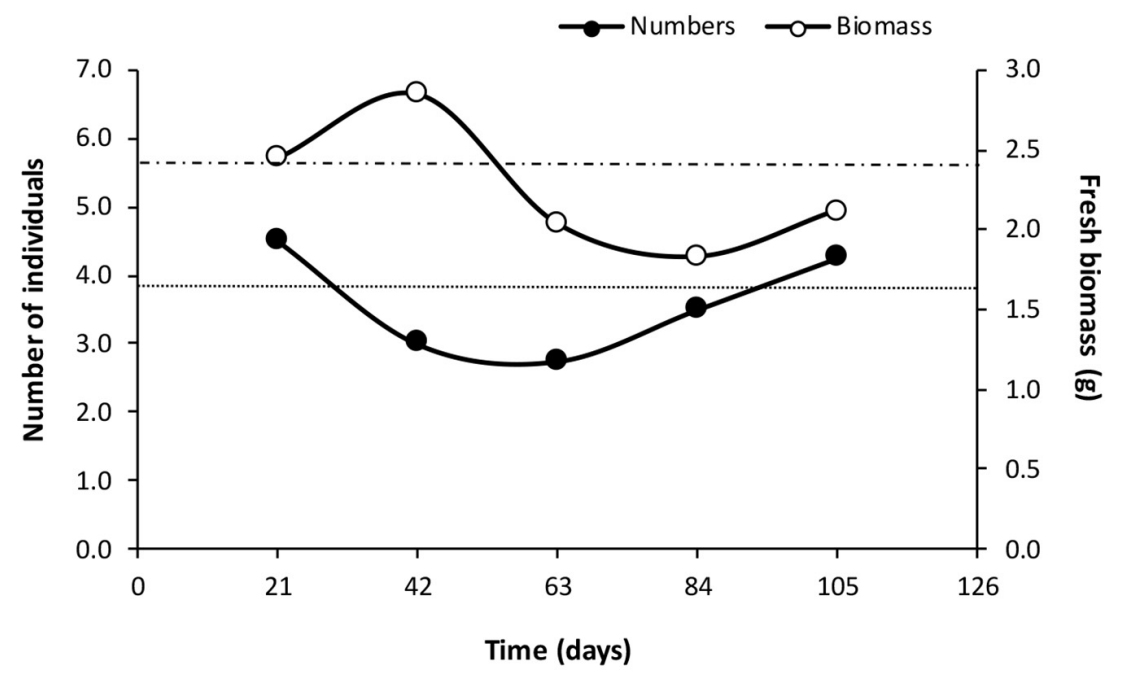

B

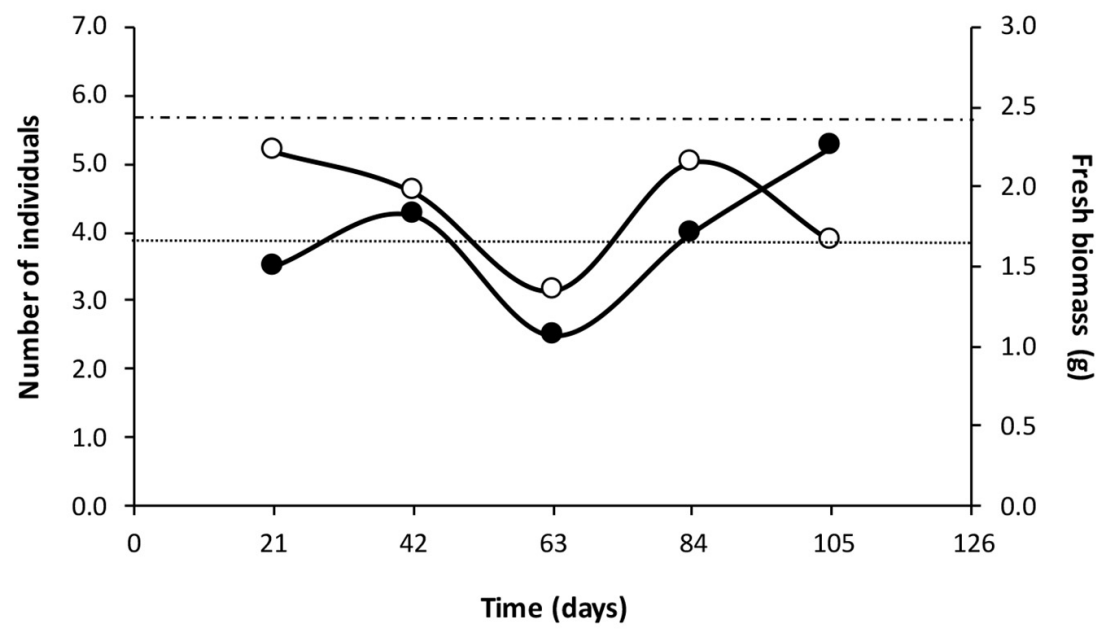

C

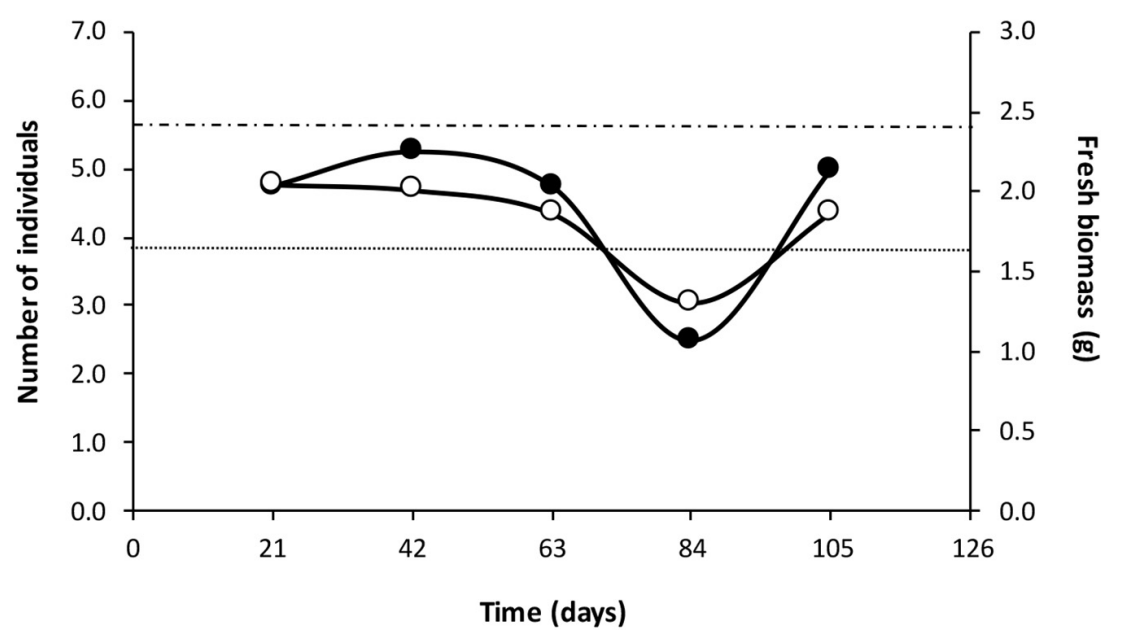

FIGURE 2 | Changes in the average values of earthworm numbers and fresh biomass at each agricultural management treatment with earthworm additions $[(\mathbf{A}) \mathrm{CONV}+\mathrm{EW}, \mathbf{( B )}$ INT + EW, and (C) ORG + EW] during the incubation period. Upper dashed line indicates initial biomass and bottom dotted line initial number of individuals inoculated in the experimental units. 


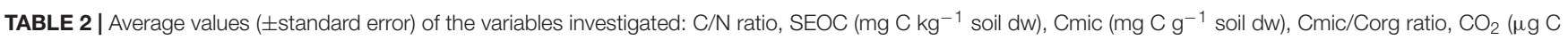
$\mathrm{g}^{-1}$ soil $\mathrm{dw} \mathrm{d}^{-1}$ ), DOC ( $\mathrm{mg} \mathrm{kg}^{-1}$ soil $\mathrm{dw}$ ), and the DOC/DON ratio measured at the three kiwifruit orchards under different management practices.

\begin{tabular}{|c|c|c|c|c|c|c|c|c|c|c|c|c|c|c|}
\hline & $\mathrm{C} / \mathrm{N}$ & & SEOC & & Cmic & & Cmic/C & & $\mathrm{CO}_{2}$ & & DOC & & DOC/DON & \\
\hline \multirow[t]{2}{*}{ CONV } & 14.33 & a & 73.33 & a & 0.44 & a & 0.25 & $a$ & 18.03 & $a$ & 4.24 & a & 1.41 & a \\
\hline & (0.19) & & $(2.02)$ & & $(0.03)$ & & (0.03) & & $(0.81)$ & & $(0.38)$ & & $(0.23)$ & \\
\hline \multirow[t]{2}{*}{ INT } & 13.91 & a & 71.75 & a & 0.38 & a & 0.20 & a & 11.36 & $b$ & 1.70 & $\mathrm{~b}$ & 1.39 & a \\
\hline & $(0.26)$ & & $(1.32)$ & & $(0.04)$ & & $(0.02)$ & & $(0.59)$ & & $(0.09)$ & & $(0.29)$ & \\
\hline \multirow[t]{2}{*}{ ORG } & 11.01 & $b$ & 77.15 & a & 0.34 & a & 0.11 & $b$ & 7.28 & C & 1.98 & $\mathrm{~b}$ & 1.30 & a \\
\hline & $(0.11)$ & & (1.67) & & $(0.04)$ & & (0.02) & & $(0.40)$ & & (0.09) & & $(0.15)$ & \\
\hline
\end{tabular}

Different letters represent significant differences between managements (Tukey's Studentized range (HSD) test, $p<0.05$ ).

TABLE 3 | Results from repeated measures of ANOVA for the time and time $\times$ treatment (agricultural management and earthworm additions combined) effects on the variables investigated: $\mathrm{C} / \mathrm{N}$ ratio, SEOC (mg C kg-1 soil dw), Cmic (mg C g ${ }^{-1}$ soil $\mathrm{dw}$ ), Cmic/Corg ratio, soil respiration ( $\mu \mathrm{g} \mathrm{C} \mathrm{g}^{-1}$ soil $\mathrm{dw}^{-1}$ ), DOC ( $\mathrm{mg} \mathrm{kg}^{-1}$ soil $\mathrm{dw}$ ) and the DOC/DON ratio.

\begin{tabular}{|c|c|c|c|c|}
\hline & \multicolumn{2}{|c|}{ Time } & \multicolumn{2}{|c|}{ Time $\times$ Treatment } \\
\hline & $F$ value & $p$ & $F$ value & $p$ \\
\hline $\mathrm{C} / \mathrm{N}$ ratio & 2.83 & 0.0654 & 1.18 & 0.3095 \\
\hline SEOC & 11.29 & 0.0015 & 0.66 & 0.8102 \\
\hline Cmic & 147.95 & $<0.0001$ & 1.22 & 0.2886 \\
\hline Cmic/Corg ratio & 29.23 & $<0.0001$ & 0.96 & 0.5225 \\
\hline Soil respiration & 11.78 & 0.0003 & 0.76 & 0.7415 \\
\hline DOC & 2.36 & 0.1125 & 1.91 & 0.0400 \\
\hline DOC/DON ratio & 14.93 & 0.0003 & 3.17 & 0.0015 \\
\hline
\end{tabular}

Significance multivariate test on each variable is Wilks' lambda test.

more sustainable practices on earthworms was only visible after more than 10 years.

Unlike earthworms, soil microorganisms appeared to be less sensitive to intensive agricultural management, and the soils under CONV practices had the highest microbial biomass (44\%) and Cmic/Corg ratio (24\%) when compared to the INT (38 and 20\%, respectively) and ORG treatments (33 and $11 \%$, respectively). These findings contradict previous reports indicating that these two microbial indicators are very sensitive to intensive management practices and hence, their values tend to increase after conversions to ORG farming associated to the positive effect of organic amendments on microbial growth (Carey et al., 2009; Kong et al., 2011; Ponge et al., 2013; Anderson and Paulsen, 2016). However, our CONV soils contained more carbon and nutrients available for microbial assimilation (as reflected in the values of microbial quotient Cmic-to-Corg), which is probably related to their previous use as a forest plantation. Furthermore, the results from a European study indicated that intensive agriculture affects more dramatically bigger sized soil organisms (Tsiafouli et al., 2015) and consequently, with less earthworms, less microbial grazing, and their soil communities became dominated by microorganisms.

Higher microbial biomass has also been linked to increased enzymatic activities, resulting in a greater mineralization of $\mathrm{C}$ and $\mathrm{N}$ labile fractions (Lago et al., 2019). Accordingly, in this study, more $\mathrm{CO}_{2}$ and DOC were lost from the CONV managed soils with the highest values of microbial biomass. Because microorganisms use DOC to produce their microbial biomass (Guo et al., 2019), a gradual decrease of the DOC/DON ratio was observed over time. This implies that CONV agricultural practices would not only contribute to increased soil respiration rates, but they could also lead to soil organic $\mathrm{C}$ depletion in the long term. In support of this, it has been estimated that $8 \%$ of total global soil $\mathrm{C}$ stocks may have been lost from the top two meters of the world's soil since the dawn of agriculture (Sanderman et al., 2017). From this, it can be anticipated that unless soil carbon is managed in a way that the carbon lost is re-absorbed, the negative emission targets will not be met and productivity will be further compromised by the continuous loss of soil fertility.

In contrast, ORG soils had the lowest rates of $\mathrm{C}$ losses (as $\mathrm{CO}_{2}$ and DOC), which could be explained as a result of higher humification rates of soil organic matter (i.e., lower $\mathrm{C} / \mathrm{N}$ ratio) and in turn, less nutrients being available to microorganisms (i.e., the lowest values of the microbial quotient Cmic:Corg). Therefore, microorganisms might have competed for the labile forms present in the soil solution (DOC and DON) leading to the gradual decreases in the DOC to DON ratio with time. The higher values of this ratio measured at the end of the incubation period indicated that these opposite effects between microbial biomass and the leaching of soluble $\mathrm{C}$ and $\mathrm{N}$ fractions weakened over time in the ORG treatments, more so in the presence of earthworms. In the absence of new residue additions, earthworms would have had to consume the organic $\mathrm{C}$ stored in the soil, leading microbial biomass to decrease and DOC to increase later in time (Lubbers et al., 2017; Guo et al., 2019).

C release from the INT soils was intermediate between that measured from the CONV and ORG treatments, which fits well with its consideration as a "middle course for agriculture between conventional and organic farming" (Morris and Winter, 1999). In this study, cumulative soil respiration in the INT treatment was 1.5 times lower than that in the CONV treatment but 1.5 times higher than in the ORG one, whereas the $\mathrm{C}$ lost into the soil solution were similar to the organically managed soils. The advantages and disadvantages of the INT farming system versus ORG or CONV ones are still under debate (Glover et al., 2000; Jonssson et al., 2010) in terms of C sequestration and crop yields. These discrepancies are probably the result of its exact meaning varying across studies and thus, the "integrated" term could refer to any farming system that relies on the use synthetic 

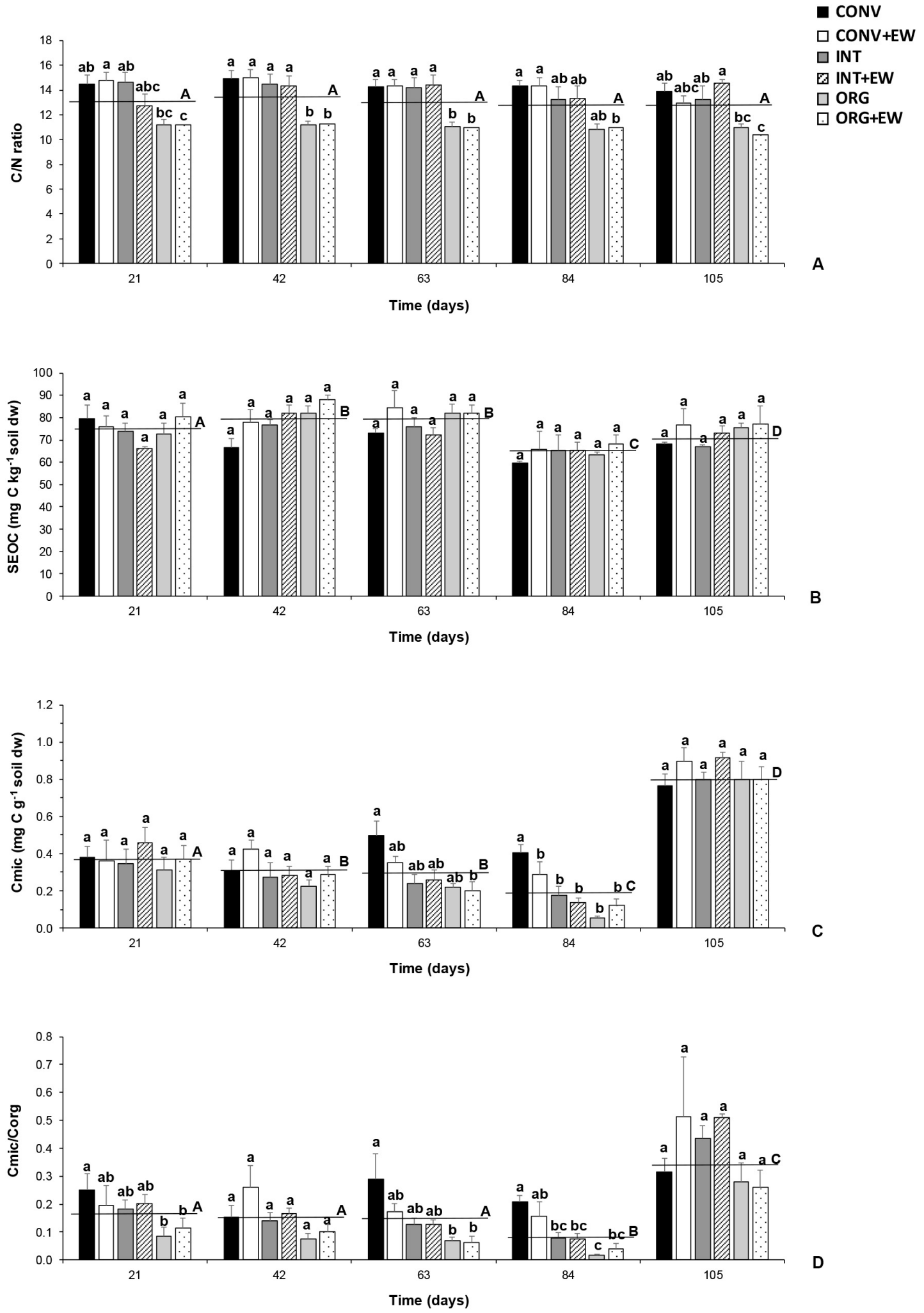

FIGURE 3 | Changes in the average values of C/N ratio (A), SEOC (mg C kg-1 soil dw) (B), Cmic (mg C g ${ }^{-1}$ soil dw) (C) and Cmic/Corg ratio (D) measured at each treatment (agricultural management and earthworm conditions combined) during the incubation period together with the averaged values per sampling time (horizontal lines). Different letters represent significant differences (repeated measures ANOVA) between treatments per sampling date (lower case) and between successive sampling times (upper case). 

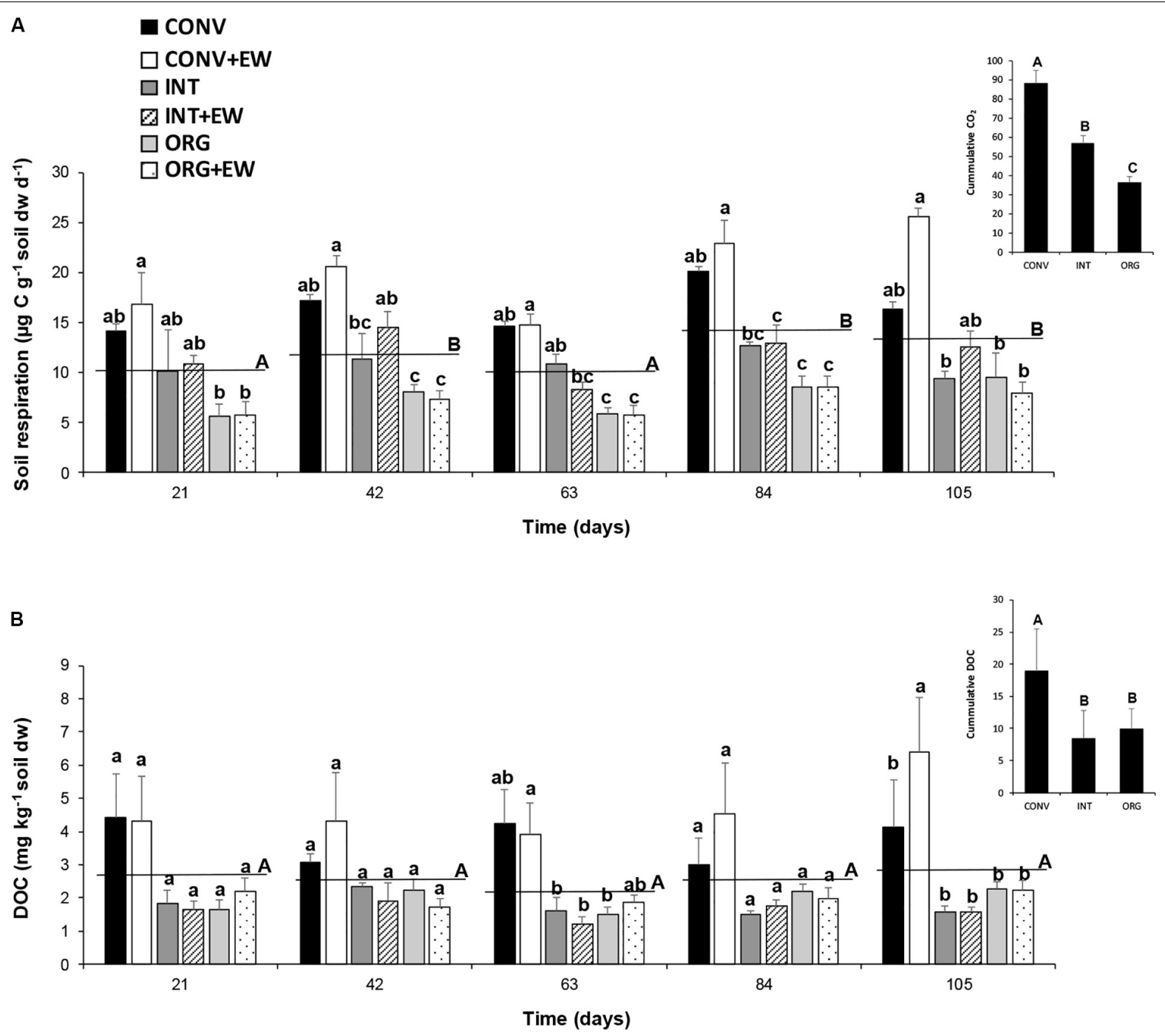

C

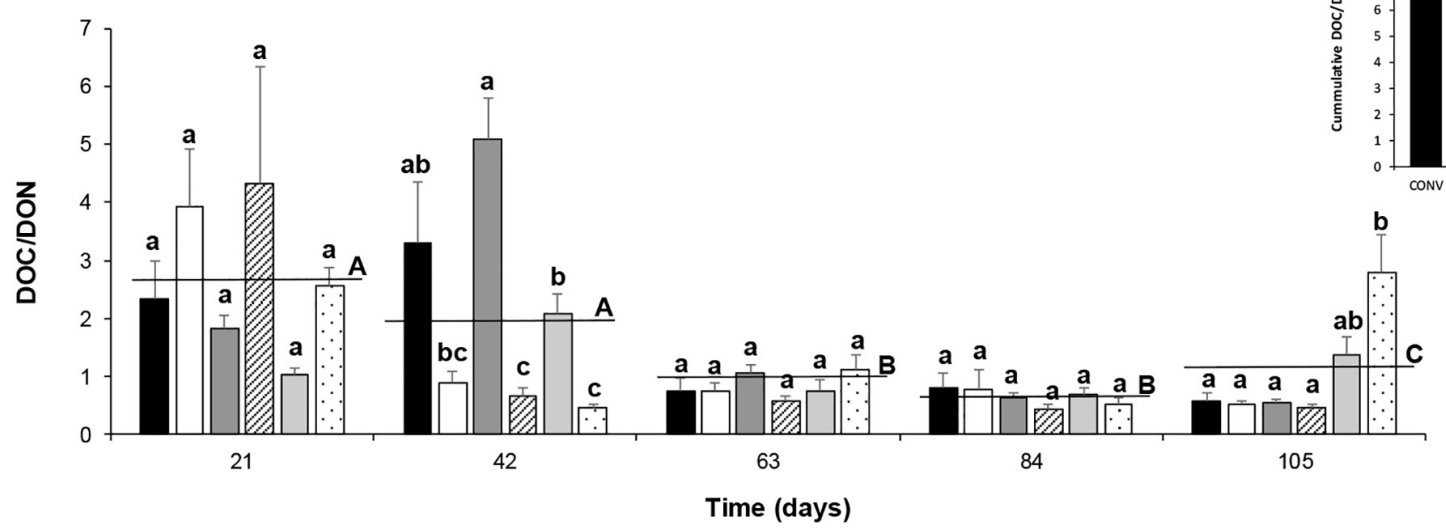

FIGURE 4 | Changes in the average values of soil respiration ( $\mu \mathrm{g} \mathrm{C} \mathrm{g}^{-1}$ soil $\mathrm{dw} \mathrm{d} \mathrm{d}^{-1}$ ) (A), DOC ( $\mathrm{mg} \mathrm{kg}^{-1}$ soil dw) (B), and DOC/DON ratio (C) measured at each treatment (agricultural management and earthworm conditions combined) during the incubation period together with the averaged values per sampling time (horizontal lines) and the accumulated values (inset). Different letters represent significant differences (repeated measures ANOVA) between treatments per sampling date (lower case) and between successive sampling times (upper case) and between treatments (ANOVA; insets). 
nitrogen fertilizers (e.g., see review by Gattinger et al., 2012), organic amendments or both (e.g., Kizos et al., 2011) and it has been suggested that reported advantages of ORG agriculture for organic $\mathrm{C}$ retention are largely determined by the massive use of organic fertilizers (Leifeld and Fuhrer, 2010).

Finally, despite the number of studies reporting enhanced $\mathrm{CO}_{2}$ emissions due to earthworm burrowing activities and their positive interactions with microorganisms (Hodge et al., 2000; McInerney and Bolger, 2000; Speratti and Whalen, 2008; Giannopoulos et al., 2010; Simek and Pižl, 2010; Lubbers et al., 2013, 2015, 2017), we found the opposite effect. Not only earthworm additions did not promote $\mathrm{CO}_{2}$ release in any of the experimental treatments, but also the cumulative values of $\mathrm{CO}_{2}$ production showed a significant decrease under those managements that contained more earthworms and less microbial biomass. Other studies have indicated that earthworms can facilitate $\mathrm{C}$ sequestration through an unequal amplification of $\mathrm{C}$ stabilization compared with $\mathrm{C}$ mineralization (the so-called "earthworm-mediated carbon trap"), whereas in the absence of earthworms, microbial effects lead to an equal unamplified processes in which each unit of $\mathrm{C}$ mineralized goes along with proportionally less C being stabilized (Zhang et al., 2013).

\section{CONCLUSION}

Although our approach to amending earthworm populations did not allow for a true control treatment without earthworms, our incubation study showed that agricultural management practices had an overruling control on $\mathrm{C}$ transformations mediated by decomposers. The lack of a significant "earthworm effect" could be due to the fact that our mesocosm experiment did not include the return of aboveground plant residues, which was the usual practice in the INT and ORG systems. Both epigeic and anecic earthworms prefer to consume the surface plant remains instead of the $\mathrm{C}$ stored in the soil, and by incorporating this new $\mathrm{C}$ down the profile and casting, they significantly enhance soil $\mathrm{C}$ stabilization (Zhang et al., 2013; Guo et al., 2019). Despite these limitations, our study showed that intensive managements not only had detrimental effects on the composition and structure of soil detrital food webs by favoring smaller sized organisms against macrofauna in agreement with previous studies (Tsiafouli et al., 2015; Lago et al., 2019), but also led to significantly greater amounts of $\mathrm{C}$ being lost from these soils. As hypothesized, the smaller relative microbial effect under ORG agricultural practices

\section{REFERENCES}

Anderson, J. M., and Ineson, P. (1982). A soil microcosm system and its application to measurements of respiration and nutrient leaching. Soil Biol. Biochem. 14, 415-416. doi: 10.1016/0038-0717(82)90015-3

Anderson, T. H., and Paulsen, H. M. (2016). Response time of soil microbial biomass after conversion from conventional to several different organic farming systems. Appl. Agric. Forestry Res. 4, 258-271. doi: 10.3220/LBF14791969 53000

Araújo, A. S., Leite, L. F., Santos, V. B., and Carneiro, R. F. (2009). Soil microbial activity in conventional and organic agricultural systems. Sustainability 1, 268-276. doi: 10.3390/su1020268 amplified $\mathrm{C}$ stabilization processes leading to less $\mathrm{CO}_{2}$ being emitted from these soils, and contrasted with the microbialdominated processes operating in the CONV system. These findings suggest that more sustainable farming practices (even a farm level) could represent a promising strategy to increase soil C sequestration and highlight the importance of other ecosystem services provided by agroecosystems beyond those derived from productivity and market values.

Further work including the effects of other influential factors, such as the soil physicochemical properties (e.g., soil texture, $\mathrm{pH}, \mathrm{CEC}$ ), the presence/absence of crop residues, and the feeding strategy of other earthworm species/ecological groups would allow for a better quantification of the overall effects of biotic interactions on the $\mathrm{C}$ balance under different agricultural managements.

\section{DATA AVAILABILITY STATEMENT}

The raw data supporting the conclusions of this article are available from the corresponding author on reasonable request.

\section{AUTHOR CONTRIBUTIONS}

MJIB and PPG developed the project design. MCFL implemented the project design. MCFL and MEB collected and analyzed the data. MCFL and MJIB drafted the manuscript with further inputs from MEB and PPG. All authors contributed to the article and approved the submitted version.

\section{FUNDING}

This work was funded by Xunta de Galicia (Grant number 10 PXIB 310142 PR and CITACA Strategic Partnership ED431E 2018/07). MCFL was supported by a Ph.D. fellowship (FPU Program AP2009-2037) and a predoctoral grant (University of Vigo).

\section{ACKNOWLEDGMENTS}

We thank the landowners of the kiwifruit orchards for access to their farms.

Bai, Z., Caspari, T., Ruiperez Gonzalez, M., Batjes, N. H., Mäder, P., Bünemann, E. K., et al. (2018). Effects of agricultural management practices on soil quality: a review of long-term experiments for Europe and China. Agric. Ecosyst. Environ. 265, 1-7. doi: 10.1016/j.agee.2018.05.028

Benge, J., Manhire, J., Pearson, A., Reid, J., and Moller, H. (2007). Differences in soil quality between and within organic and integrated management kiwifruit orchards in New Zealand. Acta Hortic. 753, 599-608. doi: 10.17660/ActaHortic. 2007.753.79

Bernard, L., Chapuis-Lardy, L., Razafimbelo, T., Razafindrakoto, M., Pablo, A.L., Legname, E., et al. (2012). Endogeic earthworms shape bacterial functional communities and affect organic matter mineralization in a tropical soil. ISME J. 6, 213-222. doi: 10.1038/ismej.2011.87 
Bos, J. F., de Haan, J., Sukkel, W., and Schils, R. L. (2014). Energy use and greenhouse gas emissions in organic and conventional farming systems in the Netherlands. NJAS Wageningen J. Life Sci. 68, 61-70. doi: 10.1016/j.njas.2013. 12.003

Bossuyt, H., Six, J., and Hendrix, P. F. (2004). Rapid incorporation of carbon from fresh residues into newly formed stable microaggregates within earthworm casts. Eur. J. Soil Sci. 55, 393-399. doi: 10.1111/j.1351-0754.2004. 00603.x

Bossuyt, H., Six, J., and Hendrix, P. F. (2006). Interactive effects of functionally different earthworm species on aggregation and incorporation and decomposition of newly added residue carbon. Geoderma 130, 14-25. doi: 10.1016/j.geoderma.2005.01.005

Briones, M. J. I., and Schmidt, O. (2017). Conventional tillage decreases the abundance and biomass of earthworms and alters their community structure in a global meta-analysis. Glob. Change Biol. 23, 4396-4419. doi: 10.1111/gcb. 13744

Bünemann, E. K., Schwenke, G. D., and Van Zwieten, L. (2006). Impact of agricultural inputs on soil organisms-a review. Soil Res. 44, 379-406. doi: 10. 1071/SR05125

Carey, P. L., Benge, J. L., and Haynes, R. J. (2009). Comparison of soil quality and nutrient budgets between organic and conventional kiwifruit orchards. Agric. Ecosyst. Environ. 132, 7-15. doi: 10.1016/j.agee.2009.02.017

Crotty, F. V., Fychan, R., Sanderson, R., Rhymes, J. R., Bourdin, F., Scullion, J., et al. (2016). Understanding the legacy effect of previous forage crop and tillage management on soil biology, after conversion to an arable crop rotation. Soil Biol. Biochem. 103, 241-252. doi: 10.1016/j.soilbio.2016.08.018

Curry, J. P., Byrne, D., and Schmidt, O. (2002). Intensive cultivation can drastically reduce earthworm populations in arable land. Eur. J. Soil Biol. 38, 127-130. doi: 10.1016/S1164-5563(02)01132-9

Diacono, M., and Montemurro, F. (2009). Long-term effects of organic amendments on soil fertility. A review. Agron. Sustain. Dev. 30, 401-422. doi: 10.1051/agro/2009040

Don, A., Steinberg, B., Schöning, I., Pritsch, K., Joschko, M., Gleixner, G., et al. (2008). Organic carbon sequestration in earthworm burrows. Soil Biol. Biochem. 40, 1803-1812. doi: 10.1016/j.soilbio.2008.03.003

Edwards, C. A., and Fletcher, K. E. (1988). Interactions between earthworms and microorganisms in organic-matter breakdown. Agric. Ecosyst. Environ. 24, 235-247. doi: 10.1016/0167-8809(88)90069-2

Emmerling, C., Udelhoven, T., and Schröder, D. (2001). Response of soil microbial biomass and activity to agricultural de-intensification over a 10 year period. Soil Biol. Biochem. 33, 2105-2114. doi: 10.1016/S0038-0717(01)00143-2

Fließbach, A., and Mäder, P. (2000). Microbial biomass and size-density fractions differ between soils of organic and conventional agricultural systems. Soil Biol. Biochem. 32, 757-768. doi: 10.1016/S0038-0717(99)00197-2

García-Orenes, F., Morugán-Coronado, A., Zornoza, R., and Scow, K. (2013). Changes in soil microbial community structure influenced by agricultural management practices in a Mediterranean agro-ecosystem. PLoS One 8:e80522. doi: 10.1371/journal.pone.0080522

Gattinger, A., Muller, A., Haeni, M., Skinner, C., Fliessbach, A., Buchmann, N., et al. (2012). Enhanced top soil carbon stocks under organic farming. PNAS 109, 18226-18231. doi: 10.1073/pnas.1209429109

Geisseler, D., and Scow, K. M. (2014). Long-term effects of mineral fertilizers on soil microorganisms-A review. Soil Biol. Biochem. 75, 54-63. doi: 10.1016/j.soilbio. 2014.03.023

Giannopoulos, G., Pulleman, M. M., and van Groenigen, J. W. (2010). Interactions between residue placement and earthworm ecological strategy affect aggregate turnover and N2O dynamics in agricultural soil. Soil Biol. Biochem. 42, 618-625. doi: 10.1016/j.soilbio.2009.12.015

Glover, J. D., Reganold, J. P., and Andrews, P. K. (2000). Systematic method for rating soil quality of conventional, organic, and integrated apple orchards in Washington State. Agric. Ecosyst. Environ. 80, 29-45. doi: 10.1016/S01678809(00)00131-6

Gougoulias, C., Clark, J. M., and Shaw, L. J. (2014). The role of soil microbes in the global carbon cycle: tracking the below-ground microbial processing of plantderived carbon for manipulating carbon dynamics in agricultural systems. J. Sci. Food Agric. 94, 2362-2371. doi: 10.1002/jsfa.6577

Guo, Y., Zhang, X., Zhang, Y., Wu, D., McLaughlin, N., Zhang, S., et al. (2019). Temporal variation of earthworm impacts on soil organic carbon under different tillage systems. Int. J. Environ. Res. Public Health 16:1908. doi: 10.3390/ ijerph 16111908

Hartmann, M., Frey, B., Mayer, J., Mäder, P., and Widmer, F. (2015). Distinct soil microbial diversity under long-term organic and conventional farming. ISME J. 9, 1177-1194. doi: 10.1038/ismej.2014.210

Henneron, L., Bernard, L., Hedde, M., Pelosi, C., Villenave, C., Chenu, C., et al. (2015). Fourteen years of evidence for positive effects of conservation agriculture and organic farming on soil life. Agron. Sustain. Dev. 35, 169-181. doi: 10.1007/s13593-014-0215-8

Hodge, A., Stewart, J., Robinson, D., Griffiths, B. S., and Fitter, A. H. (2000). Plant $\mathrm{N}$ capture and microfaunal dynamics from decomposing grass and earthworm residues in soil. Soil Biol. Biochem. 32, 1763-1772. doi: 10.1016/S0038-0717(00) 00095-X

Janzen, H. H. (1987). Soil organic matter characteristics after long term cropping to various spring wheat rotators. Can. J. Soil Sci. 67, 845-856. doi: $10.4141 /$ cjss 87-081

Jernigan, A. B., Wickings, K., Mohler, C. L., Caldwell, B. A., Pelzer, C. J., Wayman, S., et al. (2020). Legacy effects of contrasting organic grain cropping systems on soil health indicators, soil invertebrates, weeds, and crop yield. Agric. Syst. 177:102719. doi: 10.1016/j.agsy.2019.102719

Jonssson, A., Nybom, H., and Rumpunen, K. (2010). Fungal disease and fruit quality in an apple orchard converted from integrated production to organic production. J. Sustain. Agric. 34, 15-37. doi: 10.1080/10440040903396565

Kizos, T., Veikontis, G., and Marín-Guirao, J. I. (2011). Comparison of organic and integrated farming systems: the case of sultana table grapes in Korinthos. Greece. J. Sustain. Agric. 35, 27-47. doi: 10.1080/10440046.2011.530499

Kong, A. Y. Y., Scow, K. M., Córdova-Kreylos, A. L., Holmes, W. E., and Six, J. (2011). Microbial community composition and carbon cycling within soil microenvironments of conventional, low-input, and organic cropping systems. Soil Biol. Biochem. 43, 20-30. doi: 10.1016/j.soilbio.2010.09.005

Krishnamoorthy, R. V., and Vajranabhaiah, S. N. (1986). Biological activity of earthworm casts: an assessment of plant growth promotor levels. Proc. Indian Acad. Sci. Anim. Sci. 95, 341-351. doi: 10.1007/bf03179368

Lago, M. C. F. (2015). Efecto del Manejo Agrícola Sobre las Propiedades Biológicas y Químicas de los Suelos y los Procesos de Transformación de la Materia Orgánica en Cultivos de kiwi (Actinidia Deliciosa). PhD Thesis, University of Vigo, Vigo.

Lago, M. C. F., Gallego, P. P., and Briones, M. J. I. (2019). Intensive cultivation of kiwifruit alters the detrital foodweb and accelerates soil $\mathrm{C}$ and $\mathrm{N}$ losses. Front. Microbiol. 10:art686. doi: 10.3389/fmicb.2019.00686

Leifeld, J., and Fuhrer, J. (2010). Organic farming and soil carbon sequestration: what do we really know about the benefits? Ambio 39, 585-599. doi: 10.1007/ s13280-010-0082-8

Lori, M., Symnaczik, S., Mäder, P., De Deyn, G., and Gattinger, A. (2017). Organic farming enhances soil microbial abundance and activity-A meta-analysis and meta-regression. PLoS One 12:e0180442. doi: 10.1371/journal.pone. 0180442

Lubbers, I. M., Pulleman, M. M., and Van Groenigen, J. W. (2017). Can earthworms simultaneously enhance decomposition and stabilization of plant residue carbon? Soil Biol. Biochem. 105, 12-24. doi: 10.1016/j.soilbio.2016.11.008

Lubbers, I. M., van Groenigen, K. J., Brussaard, L., and van Groenigen, J. W. (2015). Reduced greenhouse gas mitigation potential of no-tillage soils through earthworm activity. Sci. Rep. 5:13787. doi: 10.1038/srep13787

Lubbers, I. M., van Groenigen, K. J., Steven, J. F., Six, J., Brussaard, L., and van Groenigen, J. W. (2013). Greenhouse-gas emissions from soils increased by earthworms. Nat. Clim. Chang. 3, 187-194. doi: 10.1038/nclimate1692

Makarov, M. I., Malyshevaa, T. I., Menyailo, O. V., Soudzilovskaia, N. A., Van Logtestijn, R. S. P., and Cornelissen, J. H. C. (2015). Effect of K2SO4 concentration on extractability and isotope signature $\left(\delta^{13} \mathrm{C}\right.$ and $\left.\delta^{15} \mathrm{~N}\right)$ of soil C and N fractions. Eur. J. Soil Sci. 66, 417-426. doi: 10.1111/ejss.12243

MAPA (2019). Anuario de Estadística Agroalimentaria del Ministerio de Agricultura, Pesca y Alimentación. Avaliable at: https://www.mapa.gob.es/ es/estadistica/temas/publicaciones/anuario-de-estadistica (accessed November $25,2019)$.

Marumoto, T., Anderson, J. P. E., and Domsch, K. H. (1982). Mineralization of nutrients from soil microbial biomass. Soil Biol. Biochem. 14, 469-475. doi: 10.1016/0038-0717(82)90106-7

McInerney, M., and Bolger, T. (2000). Temperature, wetting cycles and soil texture effects on carbon and nitrogen dynamics in stabilized earthworm 
casts. Soil Biol. Biochem. 32, 335-349. doi: 10.1016/S0038-0717(99) 00158-3

Medina-Sauza, R. M., Álvarez-Jiménez, M., Delhal, A., Reverchon, F., Blouin, M., Guerrero-Analco, J. A., et al. (2019). Earthworms building up soil microbiota, a review. Front. Environ. Sci. 7:81. doi: 10.3389/fenvs.2019.00081

Merino, A., Otero, V., Omil, B., Lastra, B., Piñeiro, V., and Gallego, P. P. (2006). Application of wood ash compared with fertilization for improving the nutritional status and fruit production of kiwi vines. J. Plant. Nutr. Soil Sci. 169, 127-133. doi: 10.1002/jpln.200520518

Morris, C., and Winter, M. (1999). Integrated farming systems: the third way for European agriculture? Land Use Policy 16, 193-205. doi: 10.1016/S02648377(99)00020-4

Nemecek, T., Dubois, D., Huguenin-Elie, O., and Gaillard, G. (2011). Life cycle assessment of Swiss farming systems: I. Integrated and organic farming. Agric. Syst. 104, 217-232. doi: 10.1016/j.agsy.2010.10.002

Noguera, D., Rondón, M., Laossi, K. R., Hoyos, V., Lavelle, P., Cruz de Carvalho, M. H., et al. (2010). Contrasted effect of biochar and earthworms on rice growth and resource allocation in different soils. Soil Biol. Biochem. 42, 1017-1027. doi: 10.1016/j.soilbio.2010.03.001

Ordóñez, R., Gonzalez, P., Giráldez, J. V., and Pera, F. (2007). Soil properties and crop yields after 21 years of direct drilling trials in southern Spain. Soil Till. Res. 94, 47-54. doi: 10.1016/j.still.2006.07.003

Orgiazzi, A., Bardgett, R. D., Barrios, E., Behan-Pelletier, V., Briones, M. J. I., Chotte, J. L., et al. (2016). Global Soil Biodiversity Atlas. Luxembourg: Publications Office of the European Union.

Otero, V. (2008). Cultivo del Kiwi: Técnicas Aplicadas a la Mejora de la Producción $y$ Conservación. PhD Thesis, University of Vigo, Vigo.

Otero, V., Barreal, M. E., Martínez-Núñez, L., Gallego, P. P., et al. (2008). Nutritional status of kiwifruit in organic and conventional farming systems. Acta Hortic. 868, 155-160. doi: 10.17660/ActaHortic.2010.868.17

Pérès, G., Piron, D., Bellido, A., Goater, C., and Cluzeau, D. (2008). Earthworms used as indicators of agricultural management. Fresen. Environ. Bull. 17, 11811189.

Ponge, J. F., Pérès, G., Guernion, M., Ruiz-Camacho, N., Cortet, J., Pernin, C., et al. (2013). The impact of agricultural practices on soil biota: a regional study. Soil Biol. Biochem. 67, 271-284. doi: 10.1016/j.soilbio.2013.08.026

Postma-Blaauw, M. B., de Goede, R. G. M., Bloem, J., Faber, J. H., and Brussaard, L. (2010). Soil biota community structure and abundance under agricultural intensification and extensification. Ecology 91, 460-473. doi: 10.1890/09-0666.1

Rede de Avisos Agrícolas (2009). Consellería do Medio Rural. Santiago de Compostela: Xunta de Galicia.

Riley, W. J., Ortiz-Monasterio, I., and Matson, P. A. (2001). Nitrogen leaching and soil nitrate, nitrite, and ammonium levels under irrigated wheat in Northern Mexico. Nutr. Cycling Agroecosyst. 61, 223-236. doi: 10.1023/A:1013758116346

Sanderman, J., Hengl, T., and Fiske, G. K. (2017). Soil carbon debt of 12,000 years of human land use. PNAS 114, 9575-9580. doi: 10.1073/pnas.1706103114

Sas Institute Inc (2011). Base SAS ${ }^{\circledR} 9.3$ Procedures Guide. Cary, NC: SAS Institute Inc.

Schrama, M., de Haan, J. J., Kroonen, M., Verstegen, H., and Van der Putten, W. H. (2018). Crop yield gap and stability in organic and conventional farming systems. Agric. Ecosyst. Environ. 256, 123-130. doi: 10.1016/j.agee.2017.12.023

Seufert, V., Ramankutty, N., and Foley, J. A. (2012). Comparing the yields of organic and conventional agriculture. Nature 485, 229-232. doi: 10.1038/ nature 11069

Simek, M., and Pižl, V. (2010). Soil flux $\mathrm{CO}_{2}$ affected by Aporrectodea caliginosa earthworms. Cent. Eur. J. Biol. 5, 364-370. doi: 10.2478/s11535-0100017-1
Singh, A., and Singh, G. S. (2019). Is earthworm a protagonist or an antagonist in greenhouse gas (GHG) emissions from the soil? Int. J. Environ. Sci. Technol. 16, 1145-1158. doi: 10.1007/s13762-018-1922-5

Smith, O. M., Cohen, A. L., Rieser, C. J., Davis, A. G., Taylor, J. M., Adesanya, A. W., et al. (2019). Organic farming provides reliable environmental benefits but increases variability in crop yields: a global meta-analysis. Front. Sustain. Food Syst. 3:82. doi: 10.3389/fsufs.2019.00082

Sparling, G. P. (1992). Ratio of microbial biomass carbon to soil organic carbon as a sensitive indicator of changes in soil organic matter. Aust. J. Soil Res. 30, 195-207. doi: 10.1071/SR9920195

Speratti, A. B., and Whalen, J. K. (2008). Carbon dioxide and nitrous oxide fluxes from soil as influenced by anecic and endogeic earthworms. Appl. Soil Ecol. 38, 27-33. doi: 10.1016/j.apsoil.2007.08.009

Srinithi, M., and Brian, R. (2010). Effect of earthworms on nutrients dynamics in soil and growth of crop. Res. J. Chem. Environ. 14, 39-44.

Tardy, V., Spor, A., Mathieu, O., Lévèque, J., Terrat, S., Plassart, P., et al. (2015). Shifts in microbial diversity through land use intensity as drivers of carbon mineralization in soil. Soil Biol. Biochem. 90, 204-213. doi: 10.1016/j.soilbio. 2015.08.010

Tsiafouli, M. A., Thebault, E., Sgardelis, S. P., de Ruiter, P. C., van der Putten, W. H., Birkhofer, K., et al. (2015). Intensive agriculture reduces soil biodiversity across Europe. Glob. Change Biol. 21, 973-985. doi: 10.1111/gcb.12752

van Eekeren, N., Bommelé, L., Bloem, J., Schouten, T., Rutgers, M., de Goede, R., et al. (2008). Soil biological quality after 36 years of ley-arable cropping, permanent grassland and permanent arable cropping. Appl. Soil Ecol. 40, 432-446. doi: 10.1016/j.apsoil.2008.06.010

Vance, E. D., Brookes, P. C., and Jenkinson, D. S. (1987). An extraction method for measuring soil microbial biomass C. Soil Biol. Biochem. 19, 703-707. doi: 10.1016/0038-0717(87)90052-6

Verhulst, N., Grovaerts, B., Verachtert, E., Castellanos-Navarrete, A., Mezzalama, M., Wall, P. C., et al. (2010). "Conservation agriculture, improving soil quality for sustainable production systems?," in Advances in Soil Science: Food Security and Soil Quality, eds R. Lal and B. A. Stewart (Boca Raton, FL: CRC Press), 137-208. doi: 10.1201/ebk1439800577-7

Wu, J., Joergensen, R. G., Pommerening, B., Chaussod, R., and Brookes, P. C. (1990). Measurement of soil microbial biomass C by fumigation-extraction. An automated procedure. Soil Biol. Biochem. 22, 1167-1169. doi: 10.1016/00380717(90)90046-3

Zhang, W., Hendrix, P., Dame, L. E., Burke, R. A., Wu, J., Neher, D. A., et al. (2013). Earthworms facilitate carbon sequestration through unequal amplification of carbon stabilization compared with mineralization. Nat. Commun. 4:2576. doi: 10.1038/ncomms3576

Zuoping, Z., Min, D., Sha, Y., Zhifeng, L., Qi, W., Jing, F., et al. (2017). Effects of different fertilizations on fruit quality, yield and soil fertility in field-grown kiwifruit orchard. Int. J. Agric. Biol. Eng. 10, 162-171. doi: 10.25165/ijabe.v10i2. 2569

Conflict of Interest: The authors declare that the research was conducted in the absence of any commercial or financial relationships that could be construed as a potential conflict of interest.

Copyright (c) 2020 Lago, Barreal, Gallego and Briones. This is an open-access article distributed under the terms of the Creative Commons Attribution License (CC BY). The use, distribution or reproduction in other forums is permitted, provided the original author(s) and the copyright owner(s) are credited and that the original publication in this journal is cited, in accordance with accepted academic practice. No use, distribution or reproduction is permitted which does not comply with these terms. 